\title{
DERAJAT INFEKSI FASCIOLA SP. PADA SAPI PERAH PERIODE LAKTASI
}

\section{The Infectious Degree of Fasciola sp. in Dairy Cows Lactating Period}

\author{
Aan Awaludin ${ }^{1}$, Yudhi Ratna Nugraheni' ${ }^{2}$, dan Nur Muhamad ${ }^{1}$ \\ 1Program Studi Produksi Ternak, Jurusan Peternakan, Politeknik Negeri Jember \\ 2Departemen Parasitologi, Fakultas Kedokteran Hewan, Universitas Gadjah Mada \\ Email: aanawaludin@gmail.com
}

\begin{abstract}
ABSTRAK
Tujuan penelitian adalah untuk mengetahui derajat infeksi Fasciola sp. pada sapi perah periode laktasi. Sampel yang digunakan pada penelitian ini adalah feses segar dari 53 ekor sapi perah pada masa laktasi yang diambil secara acak dari peternakan sapi perah di Kabupaten Jember. Indentifikasi infeksi Fasciola sp. dengan menemukan telur Fasciola sp. pada sampel feses dengan metode sedimentasi, derajat infeksi diperoleh dengan menghitung jumlah telur cacing per gram (EPG/Eggs per gram) menggunakan Whitlock chambers. Hasil penelitian didapatkan 30 sampel feses ditemukan adanya telur Fasciola sp. dengan derajat infeksi termasuk dalam kategori ringan.
\end{abstract}

Kata kunci: Cacing, Fasciola, Infeksi, Sapi Perah, Telur

\section{ABSTRACT}

The objective of this study was to determine the infectious degree of Fasciola sp. in dairy cows during the lactation period. The sample used was fresh feces from 53 dairy cows during lactation, which was taken randomly from dairy farms in the Jember District. The identification of Fasciola sp. did by finding eggs of Fasciola sp. from feces sample using the sedimentation method. The infectious degree was obtained by counting the number of worm eggs per gram (EPG) using Whitlock chambers. The results showed that 30 feces samples found eggs of Fasciola sp., with the infectious degree on the slight category.

Keywords: Worms, Fasciola, Infection, Dairy Cows, Egg

\section{PENDAHULUAN}

Peternakan sapi perah menjadi salah satu usaha di bidang peternakan yang mempunyai peluang dan potensi untuk dikembangkan. Hal tersebut didukung oleh keadaan alam di Indonesia yang relatif mendukung untuk usaha tersebut, disamping juga kebutuhan konsumsi susu nasional yang semakin meningkat (Asmara et al., 2016). Amam \& Harsita (2019) menjelaskan bahwa usaha ternak sapi perah mempunyai nilai strategis dalam mendukung pembangunan peternakan terutama dalam memenuhi kebutuhan susu sebagai salah satu sumber pangan asal ternak yang semakin meningkat sejalan dengan peningkatan jumlah penduduk. Kebutuhan susu nasional sampai saat ini baru disuplai $21 \%$ dari produk susu nasional dan sisanya sebanyak $79 \%$ disuplai dari kegiatan impor.

Pengembangan usaha peternakan termasuk di dalamnya peternakan sapi perah tidak bisa lepas dari berbagai permasalahan baik itu bersifat teknis maupun non teknis. Penyakit ternak menjadi salah satu permasalahan yang mempunyai potensi resiko yang merugikan dalam usaha ternak sapi perah disamping kondisi musim dan iklim yang saat ini tidak menentu serta aspek lain seperti aspek ekonomi yang meliputi fluktuasi harga susu serta kebijakan pemerintah maupun 
kelembagaan peternak (Syukur et al., 2014). Menurut Tantri et al. (2013), ternak yang dipelihara baik secara intensif maupun ekstensif tidak bisa lepas dari berbagai kendala penyakit ternak yang salah satunya adalah gangguan kesehatan akibat parasit cacing. Parasit cacing mampu memberikan dampak kerugian dalam usaha peternakan karena mengakibatkan ternak mengalami penurunan dalam hal produktivitas. Zalizar (2017) gangguan kesehatan karena infeksi parasit cacing pada ternak di Indonesia mampu menimbulkan kerugian yang sangat besar. Kerugian tersebut karena parasit cacing akan menyerap zat-zat makanan, menghisap darah atau cairan tubuh, serta memakan jaringan tubuh ternak. Parasit cacing juga mampu menimbulkan kerusakan pada sel-sel epitel usus sehingga dapat menurunkan fungsi usus dalam proses pencernaan dan penyerapan zatzat makanan serta produksi enzim-enzim yang berperanan dalam proses pencernaan. Gangguan kesehatan akibat parasit cacing pada sapi perah menyebabkan penurunan produksi susu pada sapi perah dewasa serta menimbulkan hambatan pertumbuhan pada sapi perah muda.

Pada beberapa kasus, kejadian infeksi karena parasit cacing mampu menimbulkan kematian pada ternak sapi. Prevalensi penyebaran parasit cacing akan semakin meningkat pada musim penghujan, spesies Fasciola sp. menjadi salah satu spesies parasit cacing yang sering ditemukan dan teridentifikasi pasa sapi perah baik pada peternakan dengan sistem pemeliharaan intensif maupun ekstensif (Rajakaruna \& Warnakulasooriya, 2011). Spesies parasit cacing lainnya yang teridentifikasi pada sapi perah meliputi Haemonchus sp., Mecistocirrus sp., Oesophagostomum sp., Cooperia sp., Bunostomum sp., dan Paramphistomum sp. (Larasati et al., 2017). Awaludin et al. (2018) pada ternak sapi di Kabupaten Jember teridentifikasi berbagai spesies parasit caing antara lain Fasciola sp., Ostertagia sp., Trichostrongylus sp., Moniezia sp., Cooperia sp., Capillaria sp., Bunostomum sp., Strongyloides sp., Oesophagostomum sp., Trichuris sp., dan Toxocara sp.

Trematodosis merupakan salah satu penyakit cacingan yang disebabkan oleh parasit cacing dari kelas trematoda seperti spesies Paramphistomum sp. dan Fasciola sp. Kejadian gangguan kesehatan akibat parasit cacing dari kelas trematoda ini masih sering diabaikan oleh peternak (Affroze et al., 2013, Khedri et al., 2015). Pada peternakan yang berada di aliran sungai tingkat kejadian infeksi karena Fasciola sp. atau disebut juga sebagai Fasciolosis bisa mencapai 40\% (Nugraheni et al., 2018). Paramphistomum sp. dan Fasciola sp. merupakan parasit cacing dari spesies kelas trematoda yang banyak teridentifikasi di Indonesia.

Kejadian Fasciolosis umumnya dalam bentuk kronis yang mengakibatkan kholangitis, namun pada beberapa kasus Fasciolosis bisa bersifat akut yang mampu mengakibatkan hepatitis parenkimatosa. Setelah parasit cacing menyerang hati maka dampak berikutnya akan muncul gangguan pada proses metabolisme lemak, protein dan karbohidrat, sehingga menimbulkan gangguan pada pertumbuhan, menurunkan bobot hidup, anemia dan dapat menyebabkan kematian serta penurunan produktivitas secara umum (Hambal et al., 2013). Fasciola hepatica atau yang umumnya dikenal sebagai cacing hati merupakan parasit trematoda yang menyebabkan penurunan produksi dari ternak ruminansia domestik secara signifikan terjadi di seluruh dunia (Charlier et al., 2013). Kejadian Paramphistomosis yang disebabkan oleh spesies Paramphistomum sp. menimbulkan gangguan kesehatan yang menyebabkan kerugian ekonomi yang ditandai dengan penurunan produktifitas (Chaoudhary et al., 2015).

Penelitian ini bertujuan untuk mengetahui derajat infeksi parasit cacing Fasciola sp. pada sapi perah khususnya pada masa laktasi. Meskipun secara umum pemeliharaan sudah mengarah ke model intensif namun masih sedikit penelitian tentang gambaran gangguan kesehatan yang terjadi pada sapi perah terutama tingkat infeksi yang terjadi pada sapi perah masa produksi karena infestasi Fasciola sp., sehingga diperlukan suatu penelitian yang memberikan gambaran nyata tingkat infeksi tersebut agar bisa memberikan informasi kondisi infeksi Fasciola sp. secara nyata di 
lapangan untuk dijadikan salah satu evaluasi dalam meningkatkan produksi di peternakan sapi perah.

\section{METODE}

Penelitian ini menggunakan sampel feses segar dari 53 ekor sapi perah pada masa laktasi di Kabupaten Jember secara acak dengan tidak memperhatikan keseragaman periode laktasi dan umur ternak. Identifikasi telur cacing Fasciola sp. dengan menggunakan metode Parfitt and Banks, sampel feses seberat $1 \mathrm{~g}$ dimasukkan ke dalam mortar ditambahkan air $20 \mathrm{ml}$ kemudian dihomogenkan dan disaring. Setelah itu dimasukkan ke dalam tabung sampai setinggi $2 \mathrm{~cm}$ dari mulut tabung dan didiamkan selama 15 menit atau sampai terbentuk endapan lebih kurang $1 \mathrm{~cm}$, kemudian supernatan dibuang. Endapan yang tertinggal di dalam tabung kemudian ditambahkan air sampai ketinggian $2 \mathrm{~cm}$ dari mulut tabung dan selanjutnya didiamkan pada tabung rak sekitar 15 menit atau sampai terbentuk endapan. Supernatan kemudian dibuang disisakan endapan setinggi $1 \mathrm{~cm}$ kemudian ditambahkan 3 tetes $\mathrm{NaOH} \mathrm{10 \% ,} \mathrm{dihomogenkan,} \mathrm{kemudian} \mathrm{ditambahkan}$ air hingga setinggi $2 \mathrm{~cm}$ dari mulut tabung dan didiamkan selama 15 menit sampai terbentuk endapan. Bagian supernatant dibuang dan disisakan endapan setinggi $1 \mathrm{~cm}$, kemudian endapan tersebut ditambahkan 2 tetes methylene blue dan dibiarkan selama beberapa menit. Setelah itu dilakukan pemeriksaan telur cacing Fasciola sp. menggunakan mikroskop binokuler (10 x 10).

Identifikasi derajat infeksi Fasciola sp. menggunakan metode McMaster dengan memasukkan endapan pada pemeriksaan identifikasi telur cacing Fasciola sp. ke dalam kamar hitung McMaster dan dihitung jumlah telur cacing Fasciola sp. untuk mengetahui jumlah telur cacing Fasciola sp. per gram feses (EPG; Eggs per gram). Data dianalisis menggunakan analisis deskriptif dengan cara membandingkan hasil pengamatan dengan literatur.

\section{HASIL DAN PEMBAHASAN}

Hasil penelitian diperoleh bahwa dari 53 sampel feses sapi perah periode laktasi yang diperiksa teridentifikasi 30 sampel feses terdapat telur cacing Fasciola sp. dan 23 sampel tidak ditemukan telur cacing Fasciola sp. atau negatif Fasciolosis (Tabel 1). Pada pemeriksaan Parfitt and Banks telur cacing Fasciola sp. terlihat coklat muda keemasan, berbentuk elips, granular, mempunyai operkulum pada salah satu ujung, dan berdinding tipis. Thienpont et al. (1985) menjelaskan bahwa telur cacing Fasciola sp. mempunyai bentuk ellips, dinding tipis, granular, tidak punya blastomer, berwarna coklat keemasan, mempunyai operkulum pada salah satu pole (ujung). Telur cacing Fasciola sp. termasuk telur cacing berukuran besar dengan kisaran ukuran panjang 130-145 $\mu \mathrm{m}$ dan lebar 70-90 $\mu \mathrm{m}$.

Tabel 1. Hasil Pengamatan telur cacing Fasciola sp.

No. Sampel

Telur cacing Fasciola sp.

\begin{tabular}{cc}
\hline $1,2,3,4,6,7,8,11,12,13,18,19,21,22,24,25$, & Positif (+) \\
$26,28,29,34,35,36,37,39,41,43,45,46,49,51$ & \\
\hline $5,9,10,14,15,16,17,20,23,27,30,31,32,33$, & Negatif (-) \\
$38,40,42,44,47,48,50,52,53$ &
\end{tabular}

Total dari sampel feses yang diperiksa maka terdapat sekitar $56,6 \%$ sapi perah yang terinfestasi Fasciola sp. dan hanya sekitar 43,4\% yang tidak ditemukan adanya telur cacing Fasciola sp. atau negatif. Prosentase sapi perah sampel yang terinfestasi Fasciola sp. ini cukup tinggi, hal 
tersebut bisa dimungkinkan karena adanya berbagai faktor pendukung. Kebiasaan dalam membuat saluran limbah kotoran ternak yang langsung dialirkan ke lahan hijauan pakan ternak sehingga siklus hidup Fasciola sp. akan terus berlangsung dan memungkinkan untuk menyebar ke ternak lainnya. Pemberian pakan hijauan yang sering kali tidak dilayukan juga memungkinkan untuk penularan Fasciola sp. ke ternak karena metaserkaria yang menempel pada hijauan pakan ternak akan ikut termakan oleh ternak dan memulai kembali siklus hidup Fasciola sp. di tubuh ternak. Pada penelitian Nugraheni et al. (2018) juga menjelaskan bahwa prevalensi kejadian Fasciolosis pada peternakan sapi di aliran sungai mencapai $40 \%$ yang dimungkinkan karena siklus hidup Fasciola sp. lebih mudah berlangsung karena penyebarannya di lahan basah lebih mendukung untuk parasit cacing tersebut. Disamping itu rendahnya kontrol terhadap siput Lymnaea spp. sebagai induk semang sementara (hospes intermediet) dari Fasciola sp. juga berperan dalam penyebaran parasit cacing tersebut.

Penghitungan jumlah telur cacing per gram (EPG) untuk Fasciola sp. didapatkan hasil yang beragam dari setiap sampel positif yang tersaji dalam table 2 .

Tabel 2. Jumlah telur cacing Fasciola sp. per gram feses (EPG)

\begin{tabular}{cc}
\hline No. Sampel & Eggs per gram (EPG) \\
\hline $1,2,6,7,8,19,22,24,25,28,29,34,35,36,37$, & 1 \\
$39,43,45,46,49$, dan 51 & 2 \\
\hline 18 dan 21 & 3 \\
\hline 4,11, dan 41 & \\
\hline
\end{tabular}

EPG telur Fasciola sp. dari 30 sampel positif didapatkan hasil antara 1-3 dengan rata-rata dari keseluruhan sampel positif adalah 1,3. EPG dengan rata-rata 1,3 ini digolongkan dalam kejadian infeksi ringan. Thienpont et al. (1985) mengelompokkan skor atau derajat infeksi parasit cacing ke dalam 4 kategori berdasarkan jumlah telur cacing per gram. Kategori tersebut adalah tidak ada infeksi dengan tidak ditemukannya telur cacing dalam feses (0), derajat infeksi ringan (slight infection) dengan EPG 1-500 (+), derajat infeksi sedang (moderate infection) dengan EPG 500-5000 $(++)$, dan derajat infeksi berat (heavy infection) dengan EPG $>5000(+++)$.

Kasus infeksi parasit cacing pada ternak dengan derajat ringan tidak menimbulkan gejala klinis. Disamping itu kejadian infeksinya juga umumnya bersifat kronis. Pada beberapa kasus produksi susu tidak akan terlihat mengalami penurunan yang signifikan kecuali jika ada faktor lain yang bisa menyebabkan penurunan produksi susu seperti nutrisi atau gangguan kesehatan lain yang mengiringi kejadian infeksi parasit caing ringan.

Solusi yang bisa dilakukan untuk meminimalkan dan mengendalikan infeksi Fasciola sp. pada ternak sapi perah yaitu dengan menerapkan program pengobatan cacing yang bisa dilakukan pada masa kering dan juga mengontrol limbah peternakan serta perlakuan hijauan pakan ternak yang dilayukan terlebih dahulu sebelum diberikan kepada ternak. Pengecekan telur cacing pada feses ternak secara sampling juga sebaiknya dilakukan secara berkala untuk memantau penyebaran dan mengevaluasi kegiatan pengendalian parasit tersebut pada ternak.

\section{KESIMPULAN}

Fasciola sp. masih menjadi salah satu parasit cacing yang sering ditemukan pada sapi perah. Derajat infeksi Fasciola sp. pada ternak sapi perah periode laktasi di Kabupaten Jember dikelompokkan pada kategori ringan. 


\section{DAFTAR PUSTAKA}

Affroze, S., Begum, N., Islam, M. S., Rony, S. A., Islam, M. A., \& Mondal, M. M. H. (2013). Risk factors and gross pathology of bovine liver fluke infection at netrokona district. Bangladesh. Journal of Animal Science Advances, 3(2), 83-90. https://doi.org/10.5455/jasa.20130219031948.

Amam, A., \& Harsita, P. A. (2019). Pengembangan usaha ternak sapi perah: evaluasi konteks kerentanan dan dinamika kelompok. Jurnal Ilmiah Ilmu-Ilmu Peternakan, 22(1), 23-34. https://doi.org/10.22437/jiiip.v22i1.7831.

Asmara, A., Purnamadewi, Y. L., \& Lubis, D. (2016). Keragaan produksi susu dan efisiensi usaha peternakan sapi perah rakyat di indonesia. Jurnal Manajemen dan Agribisnis, 13(1), 14-25. https://doi.org/10.17358/JMA.13.1.14.

Awaludin, A., Nurkholis, \& Nusantoro S. (2018). Identify the Diversity of Helminth Parasites in Cattle in Jember district (East Java - Indonesia). In IOP Conference Series: Earth and Environmental Science (Vol 207). https://doi.org/10.1088/1755-1315/207/1/012032

Chaoudhary, V., Hasnani, J, J., Khyalia, M, K., Pandey, S., Chauhan, V, D., Pandya, S, S., \& Patel, P, V. (2015). Morphological and Histological Identification of Paramphistomum cervi (Trematoda: Paramphistoma) in the Rumen of Infected Sheep. Veterinary World, 8(1), 125-129. https://doi.org/10.14202/vetworld.2015.125-129.

Charlier, J., Vercruysse, J., Morgan, E., Van Dijk, J., \& Williams, D. J. L. (2013). Recent Advances in the Diagnosis, Impact on Production and Prediction of Fasciola hepatica in cattle. Parasitology, 141(3), 326-335. https://doi.org/10.1017/S0031182013001662

Hambal, M., Sayuti, A., \& Dermawan, A. (2013). Tingkat kerentanan Fasciola gigantica pada Sapi dan Kerbau di Kecamatan Lhoong Kabupaten Aceh Besar. Jurnal Medika Veterinaria, 7(1), 49-53. https://doi.org/10.21157/j.med.vet..v7i1.2921.

Khedri, J., Radfar, M. H., Borji, H., \& Mirzaei, M. (2015). Prevalence and Intensity of Paramphistomum spp. in Cattle from South-Eastern Iran. Iran Journal Parasitology, 10(2), 268-272.

Larasati, H., Hartono, M., \& Siswanto. (2017). Prevalensi Cacing Saluran Pencernaan Sapi Perah Periode Juni - Juli 2016 pada Peternakan Rakyat di Provinsi Lampung. Jurnal Penelitian Peternakan Indonesia, 1(1), 8-15.

Nugraheni, Y. R., Priyowidodo, D., Prastowo, J., Rohayati, E. S., Sahara, A., \& Awaludin, A. (2018). Parasit Gastrointestinal pada Sapi di Daerah Aliran Sungai Progo Yogyakarta. Jurnal Ilmu Peternakan Terapan, 2(1), 1-5. https://doi.org/10.25047/jipt.v1i2.889

Rajakaruna, R. S., \& Warnakulasooriya, K. N. (2011). Gastrointestinal Parasites in Dairy Cattle in Kandy District in Sri Lanka. Annual Research Journal of SLSAJ, 11, 92-99.

Syukur, S. H., Fanani, Z., Nugroho, B. A., \& Antara, M. (2014). Empowerment of Livestock Farmer through Graduate Program to Build to Village on Dynamics of Beef Catle Farmers Groups Level of Gaduhan Model (A Case Study in the District of Toli-Toli, Central Sulawesi). Journal of Natural Science Research, 4(2), 107-112.

Tantri, N., Setyawati, T. R., \& Khotimah, S. (2013). Prevalensi dan Intensitas Telur Cacing Parasit pada Feses Sapi (Bos sp.) Rumah Potong Hewan (RPH) Kota Pontianak Kalimantan Barat. Jurnal Protobiont, 2(2), 102-106.

Thienpont, D., Rochette, F., \& Vanparijs, O. F. J. (1985). Diagnosing Helminthiasis by Coprological Examination. Beerse, Belgium: Janssen Research Foundation.

Zalizar, L. (2017). Helminthiasis Saluran Cerna pada Sapi Perah. Jurnal Ilmu-Ilmu Peternakan, 27(2), 116-122. https://doi.org/10.21776/ub.jiip.2017.027.02.01. 